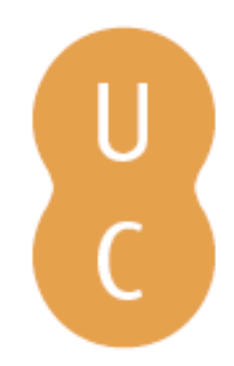

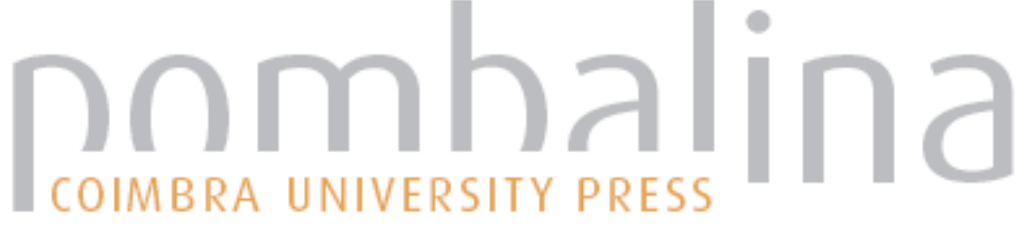

\section{Portugal na christiana respublica}
Autor(es):
Mendonça, Manuela
Publicado por: Imprensa da Universidade de Coimbra
URL persistente:
URI:http://hdl.handle.net/10316.2/38951
DOI:
DOl:http://dx.doi.org/10.14195/978-989-26-0395-7_5

Accessed : $\quad$ 26-Apr-2023 14:45:36

A navegação consulta e descarregamento dos títulos inseridos nas Bibliotecas Digitais UC Digitalis, UC Pombalina e UC Impactum, pressupõem a aceitação plena e sem reservas dos Termos e Condições de Uso destas Bibliotecas Digitais, disponíveis em https://digitalis.uc.pt/pt-pt/termos.

Conforme exposto nos referidos Termos e Condições de Uso, o descarregamento de títulos de acesso restrito requer uma licença válida de autorização devendo o utilizador aceder ao(s) documento(s) a partir de um endereço de IP da instituição detentora da supramencionada licença.

Ao utilizador é apenas permitido o descarregamento para uso pessoal, pelo que o emprego do(s) título(s) descarregado(s) para outro fim, designadamente comercial, carece de autorização do respetivo autor ou editor da obra.

Na medida em que todas as obras da UC Digitalis se encontram protegidas pelo Código do Direito de Autor e Direitos Conexos e demais legislação aplicável, toda a cópia, parcial ou total, deste documento, nos casos em que é legalmente admitida, deverá conter ou fazer-se acompanhar por este aviso.

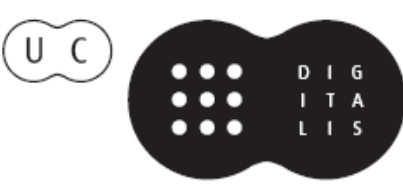


Nair de Nazaré Castro Soares

Santiago López Moreda

Coordenação

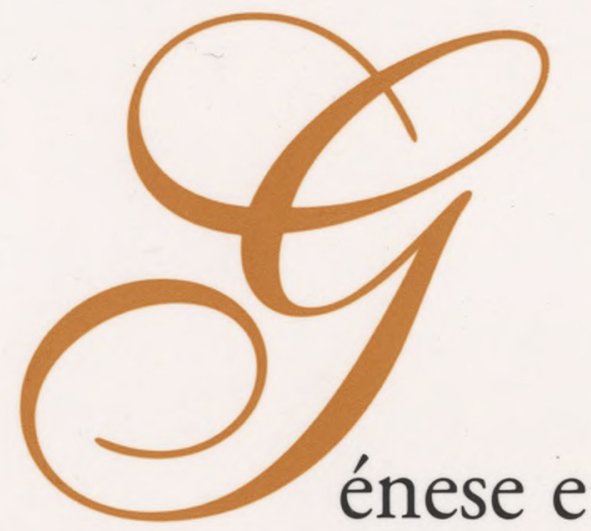

Consolidação da Ideia de Europa

Vol. IV

Idade Média e Renascimento

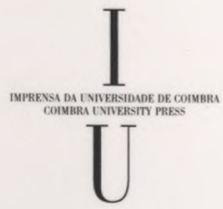

- COIMBra 2009 


\title{
PORTUGAL NA CHRISTIANA RESPUBLICA
}

\author{
MANUELA MENDONÇA \\ (Universidade de Lisboa)
}

1. Pensamos hoje, com frequência, o sentido da pertença ao continente europeu e, à força de nos acostumarmos à "ideia" de Europa, quase nos parece natural que sempre assim tenha acontecido. Contudo, essa identificação com a "casa comum" foi diversa ao longo dos tempos. No caso concreto da Idade Média portuguesa, tal noção tem cambiantes, sendo certo que, até ao século $\mathrm{XV}$, não se ia além de um sentimento difuso de um outro espaço, no qual havia diferentes povos com que era necessário estabelecer contactos e alianças. Pode dizer-se que o elo de ligação estava na sociedade que, consciente ou inconscientemente, se unia na mesma expressão religiosa, o cristianismo. E foi por esta marca que o ocidente se reconheceu, como atestam os mais diversos documentos. Os cronistas não utilizam a designação "Europa", mas sim a de "cristandade" e quando o Doutor João Teixeira apresentou, em 1485, a Oração de Obediência ao novo Papa, Inocêncio VIII, referia os "... notáveis serviços" prestados pelo "Rei João" à "República cristã e à Sé apostólica...".

No princípio do segundo quartel do século XVI, ainda Garcia de Resende identificava o velho continente com a mesma designação, num âmbito geográfico que não ia além da península itálica e da Hungria. Este autor, ao falar dos problemas políticos dos reis do ocidente escreve, "El Rey Carlos de França fazendo a maior parte da Christandade liga contra elle..." ou, mais especificamente, na Miscelânea, "Quinze reis, quinze reynados/ vimos já na christandade... ... castelhanos e franceses/ Alemães, Venezeanos/ Navarros, Aragoneses/ Napolitanos, ingleses/ Romanos, Cezelianos/ Italianos, Millaneses/ Soy-

' Oração de Obediência ao Sumo Pontifice Inocêncio VIII, dita por Vasco Fernandes de Lucena em 1485, edição com nota bibliográfica de Martim de Albuquerque e tradução portuguesa de Miguel Pinto de Meneses, Lisboa, 1988, p. 23.

${ }^{2}$ Garcia de Resende, Crónica de D. João II e Miscelânea, nova edição conforme a de 1798, com prefácio de Joaquim Veríssimo Serrão, Lisboa, 2ª . Edição, 1992, p. 220. 
ços, e Escorceses/ vimos todos batalhar/ huos com outros se matar/ salvo Ungros e Portugueses" ${ }^{3}$. Contudo, quando Damião de Góis assentou a Chronica del Rei Dom Emanuel, entre 1558 e 1567, a noção de Europa como espaço comum e interrelacionado era já muito mais nítida. Com efeito, ao descrever os pareceres emitidos no Conselho que o monarca reuniu em Montemor-o-Novo para decidir a continuidade das navegações, explica que algumas opiniões eram contrárias ao retomar do avanço, pois que tal atitude "... havia de ser muito envejada de todolos Reis, \& respublicas da Europa..." ${ }^{4}$. O cronista colocava então na boca dos intervenientes um conceito que certamente lhes seria desconhecido, mas para ele, que escrevia mais de meia centena de anos depois, era já contemporâneo! Quer isto dizer que ia adiantado o século XVI quando a consciência do espaço geográfico se sobrepôs à identificação religiosa, ainda que a preocupação nas relações e a busca do equilíbrio político tivessem sido de todos os tempos, como já ficou afirmado. Basta lembrar que, quando o rei Venturoso, depois da viagem de Vasco da Gama, se decidiu pelo desenvolvimento dos contactos com o Oriente, procurou, antes de tudo, garantir paz e alianças com os reinos cristãos. E fê-lo em três vertentes: "através das cartas que dirigiu a várias cortes, comunicando o seu propósito; por uma acção diplomática que levou a efeito junto dos seus pares; e através da política de aproximação que manteve com Espanha, num claro objectivo de viabilização de um projecto paralelo" . Abria-se então uma outra época, mas, de momento, importa-nos regressar ao tempo da "christiana respublica", para tentar recuperar as principais linhas de relação que, nela, Portugal desenvolveu.

Nascendo como Estado num desígnio concretizado pelo ritmo da reconquista, Portugal construiu-se também numa referência muito forte ao espaço europeu, no momento em que no restante ocidente já se ensaiavam as políticas centralistas. Por isso, ao pensar os históricos caminhos lusos, importa enquadrá-los nessas duas grandes linhas que se cruzaram na Península. O processo subsequente seria o fruto de outras tantas vertentes: a posição geográfica e a acção humana. Só dentro destes parâmetros será possível entender a relação de Portugal com o velho continente, onde ocupa a ponta mais ocidental. E cabe agora perguntar: que outras opções se lhe poderiam oferecer?

2. Recuando à época da recuperação da Península Ibérica pelos chamados reinos cristãos, na sequência da invasão e domínio muçulmanos, situemo-nos

\footnotetext{
${ }^{3}$ Idem, ibidem, p. 355.

${ }^{4}$ Damião de Góis, Crónica do Felicissimo Rei D. Manuel, nova edição conforme a de 1566, Coimbra, 1949, p. 38.

${ }^{5}$ Cf. Joaquim Veríssimo Serrão, Portugal e o Mundo nos Séculos XII a XVI, Lisboa, 1993, p. 143.
} 
no século XII, para já poder falar do reino de Portugal, ainda que inserido no contexto peninsular. Desde logo se destaca a posição geográfica, com grande parte do espaço aberto ao mar. Se exceptuarmos os Pirinéus, única entrada terrestre para a restante Europa, encontramos um território aberto, a norte, ao Cantábrico, a leste ao Mediterrâneo e a sul ao Atlântico. A Portugal caberia uma fronteira a norte e a leste partilhada com Castela e Leão e a ocidente e a sul banhada pelo Atlântico. Significa isto que os grandes espaços limítrofes da Península Ibérica ficam voltados para o mar, o que explica que, desde sempre, o grande oceano se tornasse factor determinante na vida destes povos.

Na senda de Jorge Borges de Macedo ${ }^{6}$, importa ter presente que os reinos aqui organizadas apenas conseguiriam atingir a maturidade política e afirmar uma existência segura, quando fossem capazes de, em cada momento, conceber e executar uma política externa autónoma. Isto é, quando tivessem capacidade para determinar e defender, em seu benefício, uma forma de equilíbrio, não apenas em termos políticos, mas também económicos. Esta imposição, quase natural, levou os estados a voltarem-se instintivamente para o mar, como porta de saída para o exterior e como factor de subsistência para os povos. Por isso os monarcas da reconquista traçaram uma estratégia que se determinou pela necessidade de assegurar as ligações com o litoral. Desse modo se deu prioridade à recuperação das grandes cidades portuárias, quer no atlântico, quer no mediterrâneo. Impunha-se libertar a costa marítima, sendo que os reinos se determinavam com a reconstituição de uma área de estuários essenciais. Por um lado, garantiam as comunicações entre duas partes da Europa: a do mar do norte e a do Mediterrâneo; e, por outro, abriam-se ao desconhecido de que o Atlântico era promessa. Numa circunstância ou noutra, o domínio da costa era essencial para o avanço e organização do espaço ibérico. Comprovando a estratégia seguida, basta lembrar que, no caso português, foi prioritário o domínio da linha do Tejo, no primeiro período da reconquista. Nesse âmbito se deve entender a conquista de Santarém, que ocorreu em 1147. Dali se rasgava o caminho para o estuário do grande rio, o que viabilizava a conquista de Lisboa, "a cidade mais poderosa que os árabes detinham na zona ocidental da Península" e que seria submetida alguns meses mais tarde. Depois dela sucumbiam os castelos de Sintra e Palmela, igualmente importantes para a abertura ao mar. Cairia depois Alcácer, em 1158, fechando-se assim o domínio estratégico das rotas do Atlântico. Idêntica política se seguira nos outros reinos

\footnotetext{
${ }^{6} \mathrm{Cf}$. Jorge Borges de Macedo, História Diplomática Portuguesa. Constantes e Linhas de Força, Lisboa, Instituto da Defesa Nacional, s/data.

Joaquim Veríssimo Serrão, História de Portugal (1080-1415), vol. I, $5^{\text {a }}$. Edição, Lisboa, 1995 , p.96.
} 
cristão peninsulares, o que se exemplifica com a conquista de Barcelona, ocorrida em 801 e a de Pamplona em 812. Com o avanço cristão, Valência cairia em 1093, Almeria em 1147, Cadiz em 1152, sendo todos importantíssimos portos marítimos, como se sabe. Em 1243 tomava-se Múrcia, depois Córdova. Daqui se assegurava o caminho para Sevilha, que viria a cair, sob Fernando III, em 1248.

Desenha-se assim uma geopolítica peninsular concertada para um objectivo comum e também vital: as ligações ao exterior, que, no momento, não ia além da "cristandade". Por isso, nunca será de mais repeti-lo, foi o mar que determinou os estados peninsulares na sua relação com o restante ocidente, ainda que, com uma dimensão sempre crescente, o Atlântico viesse a abrir portas de um mundo desconhecido, tanto a Portugal como a Espanha. Para o demonstrar basta ter presente que, logo no século XIII, nasceu a questão das Canárias, cuja posse foi disputada entre Portugal e Castela numa batalha diplomática que só teria o seu fim em $1479^{8}$. Mas esse epílogo justificava-se por outros interesses que igualmente advinham do mar, nomeadamente o domínio português do Atlântico Sul, de que ainda falaremos.

Assim se desenham, na Península Ibérica, quatro realidades a considerar: Portugal, Espanha, o Oceano e a Europa. Escrevemos já que a única ligação terrestre ao restante ocidente se fazia pelos Pirinéus. Podemos ainda acrescentar, com Fernand Braudel ${ }^{9}$, que Espanha apresentava uma maior diversidade do que Portugal na abertura marítima ao exterior. Com efeito, pelos portos do norte dominava o Cantábrico; por Barcelona se ligava a Itália e com Sevilha se abria ao Atlântico. Em Portugal apenas havia um grande porto: o de Lisboa. Talvez por isso ele foi porta para mundos diferenciados! Mas, apesar dessa condicionante, Portugal nunca viveu isolado do restante ocidente, bastando lembrar a ajuda militar recebida dos cavaleiros, nessa cruzada tão importante à "república cristã". E, depois de esboçados os estados, continuamos a ver uma relação próxima, marcada por alianças que, à boa maneira medieval, sempre foram seladas por contratos matrimoniais. No caso português poderíamos lembrar que o seu primeiro rei, D. Afonso Henriques, negociou casamento na Sabóia, procurando-o depois para os seus filhos em Castela, em Aragão e na Flandres. Os seus sucessores mantiveram a mesma política, alargando as alianças à Dinamarca, a Bolonha, a França, à Alemanha, etc. Idêntica situação ocorria nos restantes reinos peninsulares. Quer isto dizer que, se a necessidade de

${ }^{8}$ Cf. Manuela Mendonça, As Relações Externas de Portugal nos Finais da Idade Média, Lisboa, 1981.

${ }^{9}$ Cf. F. Braudel, La Méditerrannée et le Monde Méditerranéen à l'Époque de Philippe II, $3^{\mathrm{a}}$. Edição, Paris, 1976. 
alianças matrimoniais se impunha como decisiva no equilíbrio político da Península Ibérica, tal não excluía, antes supunha, o estabelecimento de outras negociações de compromisso com o restante ocidente, salvaguardada sempre a noção de que, até ao século XV, esse conceito não se estendia para lá da Península Itálica e do reino da Hungria. Para os contactos com essas paragens sabemos que os caminhos privilegiados passavam quase sempre pelo mar, numa aliança entre o Atlântico e o Mediterrâneo, que se tornou na estrada mais utilizada nessas ligações.

Por tudo isto se pode afirmar que, desde os primórdios das nacionalidades, a necessidade de ligação à cristandade esteve presente na estratégia diplomática dos reinos peninsulares. E se é certo que a sua condição geográfica determinou o desenvolvimento de uma profícua actividade marítima, não é menos verdade que essa orientação não se fez de costas para a christiana Respublica, sendo a consolidação das relações com o ocidente muito anterior à concretização da gesta atlântica. Por isso, realizada esta, o ocidente procurou por todos os meios beneficiar das novas possibilidades, objectivo que atingiria o seu ponto alto através dos reinos de Inglaterra, Holanda e França, que colocaram um particular empenho na ocupação e comércio das terras antes descobertas por Portugal e Espanha. Nesta base podemos afirmar, com Joaquim Veríssimo Serrão, que "se a génese dos descobrimentos foi estritamente peninsular, a sua irradiação europeia transformou-a numa empresa de resultados fecun$\operatorname{dos}^{\prime \prime 10}$.

3. Apesar deste destino comum aos reinos peninsulares, a verdade é que o processo interno na relação entre si nem sempre foi pacífico. $O$ equilíbrio de forças raramente foi conseguido, pelo que, com frequência, se digladiaram. A coroar a paz tendeu-se sempre para as alianças matrimoniais, sendo que a proximidade das famílias reinantes criava novos focos de instabilidade, cujo desenvolvimento ultrapassou, por vezes, as fronteiras ibéricas, para se inserir no contexto mais vasto da política da "república cristã". Tal aconteceu, por exemplo, no último quartel do século XIV, quando Portugal viu a sua independência ameaçada e teve de enfrentar Castela, numa guerra que só teria o seu epílogo na paz assinada em Medina del Campo, já no século seguinte. Este conflito não pode deixar de ser entendido no âmbito de outro confronto mais abrangentes: a guerra dos Cem Anos, que opunha França a Inglaterra, sendo Castela aliado preferencial daquele reino. A Portugal serviria o apoio de Inglaterra, que reivindicava o trono internamente usurpado em Castela aos

\footnotetext{
${ }^{10}$ Joaquim Veríssimo Serrão, Portugal e o Mundo... p. 60.
} 
descendentes de Pedro, o Cruel e ocupado pelos Transtâmara. Daqui nasceria a mais antiga aliança portuguesa, numa época em que os poderes senhoriais se confundiam ainda com os processos de afirmação régia.

$\mathrm{Na}$ sequência do conflito, os monarcas portugueses da nova dinastia - a dinastia de Avis - receando as proximidades familiares que poderiam fazer perigar de novo a independência, levantaram, mais uma vez, os olhos para os restantes reinos cristãos do ocidente, intensificando as alianças estratégicas que, acompanhadas dos necessários matrimónios, se concretizaram em Inglaterra, Borgonha Aragão e Alemanha.

Volvido um quarto de século, contudo, a tendência natural para as relações de proximidade geográfica já havia recuperado a sua força. A partir de 1455 negociaram-se novos ajustes matrimoniais ${ }^{11}$, dos quais resultariam também conflitos, sendo o principal o que levou D. Afonso V de Portugal a reivindicar a coroa de Castela, na sequência da morte de D. Henrique IV, ocorrida em Dezembro de 1474. Essa tentativa justificou-a pela necessidade de ajudar a sobrinha, D. Joana, com quem casou e em nome de quem lutou contra o exército de Isabel, irmã do monarca desaparecido, que se proclamara rainha. Neste momento da política ibérica também se jogou um xadrez de influências de outros reinos do ocidente, pois o monarca de Portugal julgou-se em sintonia com Luís XI, rei de França, em cuja ajuda acreditou. Tal se justificaria pelos diferendos que então o opunham a Castela e Aragão, na luta pela posse do Rossilhão. Mas o projecto saldou-se por uma humilhação do rei "Africano" que, numa actuação inédita na época, chegou mesmo a deslocar-se a França, onde foi um verdadeiro joguete nas mãos de Luís XI. A campanha portuguesa em Castela viria a ter o seu epílogo na paz assinada, em 1479, nas Alcáçovas e que seria ratificada, pelos Reis Católicos, no ano seguinte, em Toledo, tratado a que já nos referimos. Na assinatura desta paz jogava-se, para além do fim de uma guerra terrestre, o destino atlântico dos dois reinos, delineando-se, pela primeira vez, a partilha de um outro importante e definitivo espaço: o mar. Tal sucedeu porque os interesses dos dois beligerantes se haviam já transferido para novas áreas. Era o domínio do Atlântico que então se negociava. De facto, até meados do século, tanto Portugal como Castela haviam disputado a preponderância sobre as Canárias, ilhas cujo comércio interessava a ambos os reinos. Porém, o avanço português até à costa da Guiné, com a consequente

${ }^{11}$ Neste ano casou D. Joana, filha do rei D. Duarte, com D. Henrique IV, rei de Castela. Já em 1447 se realizara o casamento de D. Isabel, filha do infante D. João e neta de D. João I, com o rei D. João II de Castela. Do matrimónio nasceria Isabel, a futura Rainha Católica. Preferimos, no entanto, o casamento de D. Joana para o marco do restabelecimento das alianças por se tratar da filha do rei português. 
actividade comercial que se foi estabelecendo, fez alterar aquele objectivo, sendo certo que os futuros Reis Católicos pretenderam também sulcar as novas águas. Digamos que os mútuos interesses impunham então novas condições na partilha. Por isso, na paz assinada nas Alcáçovas, para além das clássicas condições que punham fim à guerra, gizava-se também um primeiro plano de divisão do mundo oceânico entre os dois reinos peninsulares: um paralelo imaginário, passando a sul das Canárias, marcaria as possessões marítimas de Espanha, que se concretizavam em todas as terras descobertas ou a descobrir a norte dessa linha. A Portugal pertenceriam todas as terras descobertas e a descobrir a sul daquele paralelo, que o mesmo é dizer, todo o atlântico sul. $\mathrm{O}$ rei português reconhecia igualmente as Canárias como possessões definitivas de Castela, terminando assim uma disputa secular. Do mesmo modo, Fernando e Isabel desistiam das suas tentativas de intromissão nas descobertas portuguesas, reconhecendo serem de Portugal os mares "contra a Guiné"12.

A letra deste tratado daria origem a novo conflito entre os reinos quando Cristóvão Colombo fez a sua primeira descoberta ao serviço dos Reis Católicos, em 1492. Era agora já e exclusivamente a importância do mar e de tudo o que ele continha, em conhecimento efectivo ou em promessa, que justificava a nova batalha diplomática travada entre D. João II de Portugal e os Reis Católicos de Espanha. O monarca português considerava sua pertença as terras encontradas no hemisfério que the coubera na partilha de 1479. Por seu lado, os reis de Espanha não pretendiam abrir mão de um "novo mundo" descoberto ao seu serviço. A importância do confronto ficou bem patente na intervenção papal, que então ainda se assumiu como mediador na cristandade, mas acabaria por ser portuguesa a imposição dos limites da nova partilha do mar oceano, assinada em Tordesilhas em 1494. A partir de então, tudo o que se viesse a descobrir a ocidente de um meridiano imaginário, passando 370 léguas a oeste de Cabo Verde, pertenceria a Espanha. Seria posse de Portugal tudo o que se conhecia ou viesse a descobrir a leste do mesmo meridiano. $\mathrm{O}$ grande mar oceano dividia-se, mais uma vez, pelos dois estados peninsulares. Mas tal não seria pacífico nos restantes reinos do ocidente, com quem o rei português se havia preocupado em estabelecer acordos de paz e amizade, mas que assim se viam arredados de um interesse que também consideravam legítimo. Esse sentimento de revolta pela injustiça ficou expresso na célebre frase atribuída a Francisco I de França, quando questionava: "Em que parte do testamento de Adão está escrito que o mundo deverá ser dividido entre Portugal e Espanha?".

\footnotetext{
${ }^{12}$ Sobre este tema pode ver-se: Manuela Mendonça, Relações Externas...
} 
4. Pelas reflexões expostas fica muito claro que a relação de Portugal com o restante ocidente é tão antiga quanto a criação do próprio estado. Poderíamos mesmo dizer que lhe é anterior, considerando a vinda de Henrique da Borgonha e os modelos políticos então importados, que culminariam na concretização do reino português. Daí a relatividade na busca do momento certo para indicar a abertura do reino ao velho continente. Tenho como certo que muitos erros cometidos no presente se poderiam evitar se os homens conhecessem melhor o passado, isto é, se dominassem o processo histórico e a dinâmica do próprio homem como agente e produto desse processo. Tal se aplica à questão actual, que sempre nos terá de conduzir à afirmação de Portugal na Europa. Por isso, consolidados os reinos como unidades políticas, importa que nos interroguemos sobre as "marchas paralelas", naquilo a que podemos chamar o esboço dos Estados Modernos, quando se tornam evidentes fortes marcas de centralização ou de "centração" de poder nos monarcas do ocidente e quando nasce a identificação da sua pessoa com o Estado. Sendo este uma abstracção, uma realidade mental, construída, quem o representa e caracteriza, quem o classifica ou leva outros a classificá-lo são os homens. Conforme o seu entendimento do poder e as posições que assumem, assim se manifesta o Estado, pelo que, depende da capacidade, da força e da autoridade dos seus agentes, que um Estado se apresente forte ou enfraquecido. Recuperemos, pois, o momento histórico em que o poder real se reencontrou e procurou afirmar-se como alternativa única, centralizadora, num caminho que conduziria aos posteriores absolutismos

Sem perder de vista que as realidades emergentes na época foram fruto, em todo o ocidente, de uma dinâmica anterior, que mergulhou as suas raizes no aumento demográfico, no crescimento das cidades, no desenvolvimento do comércio, no fortalecimento da burguesia, enfim, na recuperação da moeda como agente vital de uma nova ordem socio-económica, importa salientar a evolução política dos reinos. Deixando de lado as lutas pela Coroa Imperial, que se mantiveram sobretudo na Germânia, e também a Península Itálica, em que as cidades mercantis rivalizavam entre si, numa luta sem tréguas, da qual não estiveram ausentes os interesses dos estados pontifícios, situemo-nos nos reinos de França, Inglaterra, Espanha e Portugal, como sinónimos dos Estados europeus em processo de centralização na época de quatrocentos. Em todos eles se assistiu, numa franja temporal quase simultânea, à criação ou reorganização de Instituições fundamentais, tais foram: a justiça, o fisco e as chancelarias. Com base nelas se refez a Corte Régia, da qual emergiu uma autoridade única: a do rei.

EM FRANÇA, FOI LUís XI (1461-1483) que protagonizou o grande momento de centralização. A valorização de um poder de origem divina era de molde a 
facilitar a aceitação de um rei consagrado, mas a figura e força do filho de Filipe o Belo foram determinantes. Foi com Luis XI que a França se acostumou a ser governada por um único homem, como escreveu Michel Mollat. Para o conseguir, o monarca realizou profundas mudanças, nomeadamente no campo da justiça. Reformando essa Instituição, já tradicionalmente liderada pelo rei, Luis XI apresentou-se como a esperança para o seu povo, enquanto era temido pelos grandes senhores. Por outro lado, dotou de poderes reforçados os seus oficiais, mantendo com eles uma estreita ligação e conheceu, como diria Chatellain, os confins do seu reino, quis saber tudo sobre todos... Numa palavra, a partir de um concreto exercício da justiça, vigiou a total acção do reino, não hesitando em sacrificar alguns dos principais nobres, que acusou de traição, isto é, de não colaboração com o projecto régio. Foi assim que rolaram as cabeças do Duque de Alençon, do conde de Armagnac e do conde de SaintPol, entre muitos outros que fez aprisionar e matar. Recuperou, pois, pelo exercício da "força" da justiça, o domínio da sociedade.

Nesta dinâmica de moralização de costumes impunha-se também tornar justos os impostos. Dessa ideia decorreu a reforma fiscal, que igualmente levou a efeito. E para um rei ser poderoso era também indispensável ter um exército forte e organizado. Com isso se preocupou igualmente o rei de França, que de tal modo levou a sério este sector do seu poder que sistematizou e deixou a seu filho, como que em testamento, no Rosier des Guerres, todas as informações que lhe pareceram importantes e também indispensáveis para o êxito, na relação de um monarca com o respectivo exército. E tinha razão, pois foi na força do seu exército que encontrou o segredo das suas vitórias na guerra. No processo de recuperação do seu reino, fora-lhe indispensável resolver problemas, nomeadamente nos domínios de fronteira, mas também internamente. Carlos o Temerário, duque da Borgonha, D. João II de Aragão e até Afonso V de Portugal, foram pedras do seu xadrez. Jogou-as e venceu, conseguindo anexar a Borgonha em 1477, Anjou em 1480, a Provença em 1481 e até Marselha se tornou uma cidade francesa, a partir do mesmo ano.

NO QUE SE REFERE A INGLATERRA, ainda que se trate de um reino com características políticas tradicionalmente diferentes, poderemos situar a viragem definitiva para o processo de centralização na acção de Henrique VII (1485-1509). Este rei iniciou a dinastia dos Tudor com a missão de fazer esquecer a terrivel Guerra das Duas Rosas, que opusera os Lencaster aos York, na sequência da Guerra dos Cem Anos.

A necessidade de se afirmar frente às grandes famílias do reino levou o novo monarca a reduzir os poderes do Parlamento, que até então reunia bienalmente. Em 24 anos de reinado, Henrique VII apenas o convocou sete vezes 
- as indispensáveis para fazer aprovar as leis que queria em vigor. A par disso, reorganizou o conselho régio, criando uma espécie de sub-conselhos: um, de homens da sua confiança, que o acompanhava nas deslocações; e outro, mais técnico e organizado, que assumia as questões da justiça, em sessões especiais, na Star Chamber, respondendo a recursos que não cabiam no âmbito dos tribunais ordinários. Foi a partir deste Conselho que reformou toda a organização judicial.

O problema económico resolveu-o sem grandes reformas, mas por medidas pontuais. Fez cobrar novos impostos à nobreza e ao clero. Exigiu comparticipações da Igreja e das organizações corporativas e aumentou os direitos sobre as novas actividades industrial e comercial, que então muito se desenvolviam.

QUANTO A ESPANHA, impõe-se destacar a acção dos reis católicos (1474-1504), Fernando de Aragão e Isabel de Castela. Este reino debatia-se com uma crise interna de autoridade que atingira a sua expressão máxima ao longo do governo de Henrique IV, o que muito contribuiu para que, à morte deste, se abrisse a crise sucessória que já referimos. Ali perto, Aragão, a braços com a ameaça francesa, interessava-lhe uma aliança de força com o reino vizinho. Depois de negociações várias, impôs-se o partido que defendia o casamento dos futuros Reis Católicos, efectuado em 1469, de que resultaria a posterior unificação dos dois reinos. Frente à divisão criada por facções de interesses diversos, Fernando e Isabel impuseram o caminho da centralização. Nesse processo viria a ser de singular importância o domínio definitivo de Granada, em 1492. Mas a reorganização do Conselho Régio, após as Cortes de Toledo (1480), que se seguiu à criação da Santa Hermandade, nascida nas Cortes de Madrigal (1476), foram as grandes responsáveis pelo restabelecimento da ordem interna.

A reforma económica foi igualmente fundamental. Fez-se através da criação de órgãos que pretenderam "moralizar" a administração. Foi o caso da Contadoria Mayor de Contas e da Contadoria Mayor da Fazenda. Para Luís Suarez Fernandes "foi a centralização das instituições, a luta contra o poder local e o enfrentar de problemas económicos que definiu a modernidade dos Reis Católicos".

EM PORTUGAL, FOI D. JOÃO II (1481-1495) que deu o grande impulso à centralização do poder. Como escreveu o saudoso Mestre, Professor Borges de Macedo, só com este rei é possível encontrar em acção um monarca que deixou de ser "um rei provido de destino", para se transformar no "rei provido de poder", encaminhando-se para "um rei de espectáculo e de parada, numa evolução de convicções tanto de "actor-rei" como de "espectadores-súbditos"

${ }^{13}$ Cf. Manuela Mendonça, D. João II. Um percurso humano e político nas origens da modernidade em Portugal, 2ª . Edição, Lisboa, 1995, introdução. 
Aliando a força dos argumentos que derrubaram as grandes casas senhoriais, a uma autoridade efectiva que percorreu todo o reino, o filho de D. Afonso V ditou em Portugal os alvores da modernidade. Se é certo que os grandes sectores da sua intervenção não andaram longe dos que nortearam os monarcas seus contemporâneos, não é menos verdade que a especificidade do momento histórico português impôs algumas medidas bem particulares. Destaquemos os principais momentos da sua intervenção:

a) Cortes de 1481/82 - nestas primeiras cortes foi dado o "tom" que iria moldar todo o reinado do sucessor de D. Afonso V. Nelas se fizeram ouvir as vozes do povo, que se queixou do que considerava a grande opressão em que vivia. Denunciavam-se as injustiças, quase todas elas decorrentes das atitudes dos grandes senhores, que actuavam totalmente à vontade nos seus domínios, sem que a autoridade régia neles se fizesse sentir. O rei respondeu e, a partir da panorâmica apresentada, como que traçou um programa de governo. E o certo é que, em 1490, quando voltou a reunir os estados do reino, a grande maioria dos problemas tinha sido resolvida. Basta dizer que, dos 172 pedidos apresentados em 1481, apenas permaneciam por resolver, em 1490, 13 questões. Esta realidade pode dar bem a noção do trabalho de recuperação efectuado em menos de dez anos. É que D. João II conhecia bem o território e as pessoas, pois desde 1475 que estivera associado ao governo de seu Pai. Não teve, por isso, dificuldade em fazer as reformas necessárias e a sua primeira grande intervenção foi precisamente para controlar os poderes das grandes casas senhoriais.

b) O domínio dos grandes - Ainda nas cortes de 1481, D. João II manifestara que não iria tolerar poderes paralelos, tendo exigido a todos os "grandes" que apresentassem documentos a provar as suas possessões e privilégios. Esta atitude foi considerada uma afronta, pelo que se torna fácil perceber o desconforto vivido e as consequentes intrigas de corte, naturalmente lideradas por quantos assumiam maior prestígio social e entendiam a atitude régia como uma humilhação. De entre estes destacou-se o Duque de Bragança, D. Fernando, indubitavelmente o homem de maior prestígio em Portugal. Detinha a segunda maior Casa do reino, estando a primeira nas mãos do Duque de Viseu, mas, juntos, constituíam um poder económico superior ao do próprio monarca. Ao segundo Duque de Viseu, D. Fernando (filho de D. Duarte e adoptivo do infante D. Henrique, de quem fora herdeiro) tinha sucedido seu filho, Diogo, que ainda era muito jovem. Tal explica que o grande lider da oposição fosse o Duque de Bragança. Acresce que estas famílias eram muito próximas da casa régia, já que o Duque de Viseu era irmão da rainha, D. Leonor e o Duque de Bragança seu cunhado. A respectiva ascendência entroncava em D. João I, pois que a casa de Bragança se formara a partir do seu filho bastardo, D. Afonso e a 
Casa de Viseu se concentrara no infante D. Henrique, também ele filho de D. João I. Entende-se, pois, que esta unidade familiar, que tantos benefícios tinha colhido na corte de $\mathrm{D}$. Afonso $\mathrm{V}$, se considerasse humilhada e injustiçada com as atitudes de D. João II. Mas para o novo rei havia a conviç̧ão de que só conseguiria controlar a autoridade no reino e impor o seu modelo de governo depois de afastar estes grandes poderes. Temos assim de um lado a força do monarca e, do outro, a força da oposição. Não é o momento de analisar em pormenor o que aconteceu e as razões que parece terem assistido a cada uma das partes. O importante é registar que, cerca de um ano depois de terminadas as cortes, D. João II anunciou ter descoberto uma conspiração liderada por D. Fernando, Duque de Bragança. Preso, foi julgado, condenado e degolado na praça pública de Évora, em 23 de Junho de 1483. Um ano mais tarde foi a vez de D. Diogo, Duque de Viseu. O rei, aceitando como certas as denúncias que teve, considerou este Duque traidor e ele próprio o assassinou em 28 de Agosto de 1484. Ficaram deste modo destruídas as principais famílias do reino. A grande maioria dos seus parentes e amigos acolheu-se a Castela e todos os seus bens foram confiscados para a "Coroa dos nossos reinos".

Com esta actuação, o filho do rei "Africano" dominou toda a nobreza, à semelhança do que fizera Luís XI em França. Recuperou economicamente o reino e abriu caminho para um governo sem oposição aparente. Com essa intenção percorreu todo o território, impondo-se como único senhor.

c) A acção régia junto dos poderes locais - Cumprida a primeira etapa da sua afirmação, o Príncipe Perfeito pôde iniciar a acção de controle de toda a actividade do reino. Para isso governou em estreita ligação com os vários sectores e, se não é certo afirmar que favoreceu os poderes locais, a verdade é que é inegável que os dotou de uma organização própria, permitindo-lhes um caminho autónomo, mas no qual a autoridade régia se apresentava como referência intransponível. Assim sendo, moralizou os costumes pela imposição da periodicidade no tempo de desempenho de cada ofício; favoreceu a nomeação de homens mais preparados intelectualmente; dotou todos os lugares de oficiais capazes de actuar nos diversos sectores, designadamente na administração, na justiça e no fisco. A par desta organização "semeou" o seu território de dependentes directos, designados por vassalos, que constituíam como que uma rede que garantia a presença do monarca nos locais mais afastados e eventualmente menos conhecidos de Portugal. Poderíamos dizer que, à semelhança do rei francês, também o monarca de Portugal conheceu os confins do seu território!

5. Se toda a dinâmica referida colocava o estado luso a par com o restante ocidente cristão, a verdade é que uma outra actividade o tornava diferente. 
Refiro-me à aventura marítima que prosseguia e cujos proventos colocavam o pequeno reino em posição de superioridade na cristandade de então. Iniciado por D. Henrique, esse avanço português pelo Atlântico encontrou novo timoneiro no monarca que, liderando-o pessoalmente, lhe traçou um plano e lhe deu uma marca de modernidade. Essa marca ficou bem patente na evolução dos contactos com as novas paragens.

$\mathrm{Na}$ visão de conjunto sobre a expansão quatrocentista que a maior parte dos autores geralmente oferece, muito pouco foi ainda revelado sobre a acção humana, isto é, o papel dos navegantes na sua "aproximação" a outros povos. $\mathrm{E}$, no entanto, a actuação desses mensageiros foi tão importante como o avanço das caravelas que progrediam no reconhecimento das terras em direcção ao Atlântico sul. $\mathrm{O}$ aprofundamento do papel desempenhado por esses homens obriga a uma atitude nova da parte do investigador que pretende saber não apenas quem partia, mas também que objectivos concretos prosseguia, para além da imediata descoberta. $\mathrm{O}$ filho de $\mathrm{D}$. Afonso $\mathrm{V}$ não os escolheu ao acaso, mas teve a preocupação de encontrar o perfil apropriado a cada missão. E a questão é esta: homens ao encontro de outros homens, que diplomacia desenvolveram no processo? Os enviados por D. Henrique e por D. João II foram diplomatas, simples mediadores ou, ao contrário, desempenharam apenas o papel do agressor?

Tendo presente que a diplomacia é uma arte que remonta à Antiguidade e que, na história portuguesa e também europeia, o embaixador residente foi uma criação da Idade Moderna, certo é que, ao longo de toda a Idade Média, sempre se constituíram embaixadas para as mais diversas missões. Neste sentido e com a convicção de que um povo, conhecido ou desconhecido, é uma pessoa colectiva e moral que importa respeitar, torna-se evidente que qualquer tipo de relacionamento implica a criação de diversos espaços de diálogo. É para tão urgente tarefa que servem os embaixadores. Para tanto escolheu o Príncipe Perfeito os seus capitães, numa inequívoca marca de modernidade, pois o estabelecimento de relações com os povos encontrados ao longo da costa africana tornou-se no seu principal objectivo. Por isso se preocupou em nomear aqueles que pudessem exercer a arte da diplomacia, mesmo que ela se identificasse com a posterior definição de la Bruyère ${ }^{14}$, para quem "a política dos embaixadores tende para um único fim que é não ser enganado, mas enganar". Esta perspectiva decerto norteou alguns contactos, como veremos, mas ela não impediu que significativas alterações viessem a registar-se no comportamento dos portugueses e dos africanos. E para o entendimento da régia mentalidade

${ }^{14}$ Citado por Jules CAMBON, Le Diplomate, Paris, 1926, p. 13 
importa conhecer os homens seleccionados para o cumprimento da missão de procurar outros povos. Em consequência, pergunte-se: tratou-se de missões confiadas a homens assumidamente enviados pelo poder régio ao encontro dos seus homólogos? Por outras palavras, podem esses emissários ser incluídos no número dos agentes que Calvet de Magalhães ${ }^{15}$ chamou diplomatas, isto é "aquele que representa um poder entre dois detentores de poder político para estabelecer contactos de vária ordem entre as duas unidades políticas"? Cremos que sim. Contudo, a orientação inicial do infante D. Henrique terá tido outros objectivos, pelo que tal intenção não presidiu desde sempre à escolha dos seus capitães. Por isso, analisando o modo como uns e outros exerceram a respectiva missão, se pode distinguir entre os impulsos que conduziram às viagens "do tempo de D. João I e as razões que foram dando um rumo próprio à exploração da costa ocidental africana..." ${ }^{\prime 6}$. Tracemos, pois, uma breve evolução ${ }^{17}$.

Doze anos após o achamento da Madeira, o infante D. Henrique enviou Gil Eanes, criado de sua casa e residente em Lagos, a tentar a dobragem do cabo Bojador ${ }^{18}$. Embora conseguisse a proeza, trazendo mesmo ao Infante a prova do seu feito (as celebradas "rosas de Santa Maria"), Gil Eanes não satisfez a verdadeira curiosidade do Príncipe navegador. O relato que apresentou no regresso incidia na terra que lhe fora dado contemplar e que, embora não parecesse ter gente nem povoados, era "mui fresca, e graciosa". A ignorância ou omissão do enviado não satisfez o chefe, pois o desejo de D. Henrique era saber se a zona do Bojador era ou não habitada, o que determinou o envio, em 1435, de uma nova missão, capitaneada por Afonso Gonçalves Baldaia, copeiro da sua casa. A notícia que este trouxe não se mostrou ainda satisfatória: tinham visto rastos de camelos e pessoas, mas se eram residentes ou apenas caravanas em trânsito não o podiam certificar. Por tal razão, ainda no mesmo ano, foi-lhe entregue, juntamente com Gil Eanes, uma outra e mais concreta missão: a de buscarem as pessoas cujos rastos teriam eventualmente apercebido na tentativa anterior. Portanto, ao Infante não interessava ainda a exploração da costa africana, mas sim o conhecimento do local e do seu eventual

${ }^{15}$ Magalhães, José Calvet de, A Diplomacia Pura, Viseu, 1982

${ }^{16}$ Joaquim Veríssimo Serrão, História de Portugal (1415-1495), vol. II, Lisboa, 1978

17 Seguimos a informação de Gomes Eanes de Zurara, Crónica de Guiné, edição introduzida por José de Bragança, Lisboa, 1972.

${ }^{18}$ João de Barros informa, a este propósito, que Gil Eanes "já o anno passado fora a este descobrimento; e por the os tempos não terçarem bem se ffoi às Canáreas.... E porque o Infante se mostrou mal servido delle por este feito, ficou tão descontente de si, que nesta segunda viagem determinou de offerecer a vida a todolos perigos, e não vir ante o Infante sem mais certo recado do que trouxera o anno passado." (Da Ásia, Lisboa, 1778, pp. 40-41). Teria, pois, havido anteriores tentativas infrutíferas de chegar a este Cabo. 
povoamento. Para o conseguir impunha-se que enviasse bons navegadores, homens da sua Casa, que oferecessem capacidades para, ainda que pela força, the trazerem o desejado "material humano". Tal o primeiro apontamento que parece de extrema importância salientar. Em 1440 a direç̧ão da viagem coube a Antão Gonçalves, que era guarda-roupa da casa do Infante e que também levou como objectivo trazer as tão desejadas "amostras" de gente. No entanto, um outro desígnio se juntava já ao anterior: se fosse impossível recolher pessoas, os nautas deveriam ao menos buscar os lobos marinhos de que Afonso Baldaia dera notícia quando da segunda expedição ${ }^{19}$ e transportar para o reino as respectivas peles, o que conseguiram.

A busca de nativos continuou em nova expedição enviada antes do regresso de Antão Gonçalves. Tendo-se encontrado, os dois capitães fizeram, em conjunto, uma verdadeira "caça ao homem". Dela resultou uma luta com os indígenas, na qual mataram uns e aprisionaram outros. A forma de diálogo então assumida foi a do domínio e imposição de poder! Portanto, concretizado o objectivo pela força, pode dizer-se que o grito de guerra estava lançado, pelo que no futuro seria necessário o envio de capitães experimentados nas armas. O próprio Antão Gonçalves, que, em recompensa do primeiro feito, recebera "a Alcaidaria mór de Thomar, e huma comenda" para além de ser nomeado "Escrivão de sua puridade" 20 , voltaria a África com a missão de fazer regressar aos lugares de origem os índígenas que trouxera a Portugal. Não só conseguiu o seu intento, como iniciou um outro tipo de relação, a de comércio, trocando as suas presas por escravos negros e ainda por algum ouro em pó. Era a primeira vez que essa riqueza vinha, daquelas partes, ao reino de Portugal ${ }^{21}$. $\mathrm{O}$ efeito foi satisfatório, pelo que os objectivos seguintes já tinham uma outra direcção. A nova viagem, em 1443, foi confiada a Nuno Tristão, a quem se ordenou apenas a procura de mais ouro. Pode dizer-se que, a partir de então, se alargaram os interesses das missões enviadas e, apesar da persistência das velhas atitudes, os comportamentos dos portugueses foram-se progressiva-

${ }^{19}$ Afonso Gonçalves Baldaia partiu do local a que ficou a chamar-se Angra dos Cavaleiros e "obra de doze léguas foi dar em hum rio, a entrada do qual em huma coroa, que se fazia no meio, viram jazer tanta multidão de lobos marinhos, que foram assomados em número de cinco mil, dos quais mataram boa soma, de que trouxeram as pelles por naquelle tempo ser cousa mui estimada" (Barros, op. cit, p.47).

${ }^{20}$ Barros, op. cit., p.57

21 “...Vieram mais de cem pessoas ao resgate delles, por serem filhos dos mais nobres daquelles Alarves. A troco dos quaes deram dez negros de terras diffferentes, e huma boa quantidade d'ouro em pó, que foi o primeiro, que se nestas partes resgatou, donde ficou a este lugar por nome Rio do Ouro, sendo somente um esteiro d'agua salgada, que entra pela terra obra de seis léguas..." (Barros, op. cit., pg. 63) 
mente alterando. Por outro lado, os nativos africanos também iam aceitando esporádicos contactos. No entanto, sempre que a força assomava, a resposta decidida, a das setas envenenadas, não se fazia esperar. Por isso continuava a ser essencial o envio de homens experimentados na arte da guerra.

Em 1445 o infante deu um primeiro sinal de mudança, ao fazer acompanhar um escudeiro de sua casa, Gonçalo de Sintra, de um intérprete escolhido de entre os azenegues vindos a Portugal. Se o propósito era a facilidade no diálogo, ele não foi concretizado, pois o negro fugiu-lhe em Arguim. Na perseguição, Gonçalo de Sintra acabou por morrer juntamente com seis companheiros. Este foi o primeiro grande desaire dos portugueses, mas foi também o momento de tomarem consciência de que aquelas terras pertenciam a outros homens, que as ocupavam em sistemas organizados. Certamente por isso, a expedição seguinte, que rumou ao Rio do Ouro em $1446^{22}$ e era constituída por três navios, comandados, respectivamente, por Antão Gonçalves, Diogo Afonso e Gomes Pires, levava já como instruções específicas: converter os nativos, mas se tal não fosse possível, ao menos fazer a paz e assentar comércio.

Esta empresa não foi bem sucedida. Porém, ficou marcada por um acontecimento decisivo para os posteriores contactos, que teve como protagonista um escudeiro de nome João Fernandes. Este português quis ficar em terra, em contacto com os nativos e ali aguardou que os navios o fossem de novo procurar. O seu objectivo era conhecer os costumes daquelas gentes e falar-lhes do reino de Portugal $^{23}$. Sem dúvida, estamos em face do primeiro "embaixador" português, ainda que esporádico, na costa africana.

Sem que o termo embaixador possa ainda ser entendida no sentido actual do seu conteúdo, a verdade é que não encontramos outro vocábulo que mais adequadamente defina a missão que João Fernandes quis enfrentar, uma vez que ele foi mais do que um mensageiro. Emissários foram certamente todos os capitães que tentaram o diálogo, já pela via da força, já pela via do entendimento. Por isso importa classificar de outro modo os que pretenderam

${ }^{22}$ Note-se que Gomes Pires era Patrão del-Rey e seguia, por mandato do "Infante D. Pedro, que então era Regente destes Reynos, levando todos por regimento que entrassem no Rio do Ouro, e trabalhassem por converter à fé de Christo aquela bárbara gente, e quando não recebessem o baptismo, assentassem com elles paz, e trato, das quaes cousas não aceptaram alguma" (Barros, op. cit., p. 72)

${ }^{23}$ Gomes Eanes de Zurara não escondeu a sua admiração por esta atitude quando escreveu: “... Mas não me espanto tanto da vinda daqueste (um negro que pediu para vir conhecer o Infante), como de um escudeiro que ia com Antão Gonçalves, que se chamava João Fernandes, que de sua vontade lhe prouve ficar em aquela terra, somente pola ver e trazer novas ao Infante, quando quer que se acertasse de tomar" (Crónica de Guiné..., p. 140). 
ficar na terra a estabelecer contactos. Daí que, com as restrições que o objectivo determina e a consciência da amplitude do papel desempenhado, propomos, apesar de tudo, a expressão "embaixador itinerante". É uma outra etapa que se inicia.

A partir desta época torna-se possível vislumbrar uma multiplicidade de contactos, mas a verdade é que o medo determinava, em grande medida, as actuações dos nativos, mais acostumados ao uso da força pelos portugueses. Exemplo disso foi a reacção que tiveram quando Gomes Pires, na sua segunda viagem, começou por lhes oferecer presentes. A cena ocorreu no Rio do Ouro, onde o navegador já permanecera algum tempo em boa harmonia com os naturais, desempenhando também o papel do mediador e, no sentido já utilizado, de "embaixador". Mas quando ali voltou, na esperança de reatar o diálogo interrompido, foi mal recebido, o que determinou nele uma outra forma de agir: fez cativos e regressou a Portugal. Foi o exemplo da interrupção do diálogo quando o mesmo já parecia ter sido alcançado.

A nova realidade passou a ser um medir de forças mútuo e a busca de interesses de parte a parte. Se, por um lado, se ia com fins de resgate, por outro, os ataques continuavam, com as implícitas consequências, como aconteceu com Nuno Tristão que, com mais 19 homens, morreu num batel, atacado com setas envenenadas. Assim eram os avanços e recuos no processo de aproximação entre os dois continentes. Os posteriores contactos levariam ao entendimento de que se impunha calar as armas. Afinal, os "embaixadores" esporádicos e de finalidade mediadora tinham provado que só a via do diálogo poderia viabilizar o outro objectivo a que se propunham: o comércio. Esse entendimento determinou uma actuação diferente, a qual se denota no termo da regência de D. Pedro. Em 1448 o Infante D. Henrique enviou Diogo Gil "homem de muito bom saber" a assentar comércio abaixo do Cabo Não, tendo a missão sido alcançada.

Passava-se então dos "homens do infante", dos seus jovens criados em busca de glória, a "enviados" escolhidos dentre os que podiam servir o diálogo. Nessa acepção consideramos Diogo Gil como se fosse um embaixador. Como embaixador foi também enviado Fernão Afonso, que visitou o rei de Cabo Verde. João de Barros escreve que os negros acalmaram à vista da caravela que se aproximava, quando lhes foi transmitido que nela ia um embaixador. Com ele se assentaram pazes, trocaram presentes e se iniciaram trocas. No entanto, esta harmonia não impediu a morte de certo cavaleiro dinamarquês que partira com os portugueses ${ }^{24}$. Tal significa que se impunha estar atento ao mínimo

${ }^{24} \mathrm{O}$ Infante D. Henrique foi procurado por um nobre de nome Balarte, fidalgo da Corte do Rei da Dinamarca. Este homem estava desejoso de participar nas expedições portuguesas. A seu pedido, D. Henrique "mandou armar hum navio, e pelo mais honrar, man- 
pormenor, pois um passo em falso reacendia a luta. Apesar de tudo, este conjunto de referências preconiza um diferente modo de presença dos portugueses na costa africana. Assim seria no futuro.

Escasseiem informações oficiais sobre a época imediatamente posterior à morte do Infante D. Henrique. Porém, uma década depois, já os negócios de África eram confiados ao Príncipe D. João, momento a partir do qual se pode afirmar que os avanços para sul passaram, conscientemente, a revestir-se de novo carácter. Sem que, em definitivo, deixasse de haver combates, certo é que a missão a que iam os enviados de Portugal se alterou, tendo a palavra de ordem "cativar" ou "submeter" sido substituída pela expressão "assentar a paz e fazer o comércio". Seria a partir de 1481, após a subida ao trono do filho de D. Afonso $\mathrm{V}$, que a selecção dos homens incumbidos dos contactos se tornaria muito mais evidente. A primeira escolha para uma empresa de vulto recaiu em Diogo da Azambuja, o capitão nomeado por D. João II para a construção do castelo de S. Jorge da Mina ${ }^{25}$. Segundo Garcia de Resende, era "homem de muito bom saber e esforçado coração, de confiança e bondade e muitas outras qualidades....26. A sua missão era, antes de tudo, diplomática, o que permite afirmar que, enquanto no início das viagens a preocupação era a de enviar capitães que, pela força, impusessem os contactos, agora o sentido da acção alterara-se. Era necessário escolher diplomatas que soubessem também ser

dou com elle um cavalleiro da Ordem de Christo, a que chamavam Fernão d'Afonso, o qual hia em modo de Embaixador ao Rey do Cabo Verde, levando dous negros por língua, per meio dos quaes o Infante the mandava que trabalhasse por converter aquella gente pagã...... Os negros da terra por já serem costumados ver os nossos navios, tinham olho no mar, como quem se vigiava; e havendo vista deste, vieram a elles em suas almadias com mão armada, e tenção de fazer algum damno se pudessem. Mas quando acharam as linguas que the fallaram, per as quaes souberam o fundamento a que o Infante mandava o navio, e que vinha nele Embaixador, e algumas cousas pera o seu Rey, ficaram com ânimo menos indignado..." (Barros, op. cit., p. 129)

25 “Elrey D. João como já em vida delRey D. Afonso seu pai tinha o negócio da Guiné em parte do assentamento da sua Casa, e per experiência dele sabia responder com ouro, marfim, escravos, e outras cousas, que enriqueciam o seu reyno, e cada anno se descobriam novas terras, e póvos, com que a esperança do descobrimento da India por estes seus mares se accendia mais nelle: com fundamentos de Christianissimo Principe, e Barão de grande prudência, ordenou de mandar fazer huma fortaleza, como primeira pedra da Igreja Oriental (...) E sabendo que na terra, onde acudia o resgate do ouro, folgavam os negros com pannos de seda, de lã, linho, e outras cousas do serviço, e policia de casa, e que seu trato tinham mais claro entendimento, que os outros daquella costa, e que no modo do seu negociar, e communicar com os nossos davam de si sinaes pera facilmente receberem o baptismo, ordenou que esta fortaleza se fizesse em aquela parte, onde os nossos ordinariamente faziam o resgate do ouro..." (Barros, op. cit., p. 153)

${ }^{26}$ Crónica de D. João II e Miscelânea ..., p. 31) 
capitães. Se tal fosse necessário, não se excluía o uso da força, mas essa não era a primeira missão! Para demonstrar essa aliança de carácter em Diogo da Azambuja, lembremos que, na visita que fez a Caramança, senhor da terra, se vestiu e à sua gente com o luxo que a cerimónia impunha. Mas não deixou de levar também "suas armas secretas, se o tempo as pedisse",27. A força passou então a aparecer como um pressuposto da representação do poder régio. Estamos a referir-nos, pela primeira vez, ao verdadeiro sentido de um poder representado diante de outro poder, à semelhança do modelo europeu: Diogo da Azambuja, cavaleiro da casa del-Rei, tinha levado todas as credenciais, e com elas se apresentou ao senhor da terra. Reconhecidas e aceites, ali se estabeleceu para iniciar a construção da fortaleza e dinamizar o comércio, sendo o primeiro embaixador residente na costa africana.

Um outro embaixador régio enviado ao Atlântico sul foi Diogo Cão, o português que assentou o primeiro padrão, em pedra, marcando assim a presença lusa nas terras por onde passava. A sua missão era de paz, pelo que não atacou os nativos, mas antes procurou entender-se com eles, ainda que por meio de gestos. A sua mensagem foi aceite e a sua actuação também. Enviou alguns dos seus homens com presentes ao Manicongo e aguardou a resposta. Mas, como passados dias nenhum tivesse voltado, socorreu-se de um procedimento normal para a época: fez cativos de entre os naturais e regressou com eles ao reino, deixando a indicação de que voltaria a buscar os seus homens e a devolver os indígenas que levava consigo, o que na realidade aconteceu ${ }^{28}$.

${ }^{27}$ É esta a interessante descrição de João de Barros: “... sahio Diogo d' Azambuja em terra com toda sua gente vestida de louçainha, e suas armas secretas, se o tempo as pedisse. E da primeira cousa que tomou posse foi de huma grande árvore, que estava em hum teso, afastada algum tanto da aldea, lugar muy disposto para se fazer a fortaleza; em a qual arvore mandou arvorar uma bandeira das Quinas Reaes, e ao pé della armar hum altar, onde se celebrou a primeira Missa dita naquelas partes da Ethiopia (...) Acabada esta Missa (...) porque Diogo d'Azambuja esperava por Çaramança, o qual abalava já de sua aldea, poz em ordem a toda sua gente. Elle assentado em huma cadeira alta vestido em hum pelote de brocado, e com hum collar d'ouro, e pedraria, e os outros Capitães todos vestidos de festa; e assi ordenada a outra gente, que faziam huma comprida, e larga rua, pera que quando Çaramança, como também era homem, que queria mostrar seu estado, veio com muita gente posta em ordenança de guerra, com grande matinada de atabaques, bozinas, chocalhos, e outras cousas que mais estrugiam que deleitavam os ouvidos...(op. cit., p. 152)

28 "Diogo Cam vendo quanto os outros tardavam, determinou de acolher alguns daquelles negros, que entravam em o navio, e vir-se com eles pera este Reyno, com fundamento que entretanto os nossos lá onde eram podiam aprender a língua, e ver as cousas da terra, e os Negros que elle trouxesse tambem aprenderiam a nossa, com que ElRey poderia ser informado do que havia entre elles. E porque partindo-se elle sem leixar algum recado poderia danar os nossos que ficavam, tanto que recolheo em o navio quatro homens delles, disse aos outros per seus acenos, que elle se partia para levar a mostrar ao seu rey aquelles 
E mais uma vez o embaixador Diogo Cão partiu, sendo a sua acção tão bem aceite que o rei do Congo quis, também ele, fazer-se oficialmente presente junto do rei de Portugal. Por isso designou Caçuta, enviando-o "...em modo de embaixada.... ${ }^{29}$. Este nobre foi recebido na corte e, algum tempo depois da sua chegada ao reino, seria baptizado em Beja, passando a chamar-se Dom João da Silva. Também os seus companheiros, “....per suas vontades, e com muita sua instância, foram baptizados com grande solenidade, e devaçam em Beja, dos quaes ElRey, e a Raynha foram padrinhos, e assim outros Senhores de Titolo. E despois de fectos Christãos, ouve ElRey por bem que estevessem, como esteveram, em seu Reggno atee fim do anno de mil quatrocentos e noventa..."30.

Pela mesma época, João Afonso de Aveiro, um outro embaixador régio, já havia chegado a Benim, cujo rei pareceu ter-se interessado pela fé cristã. Em consequência, nesse ano de 1486, enviou, na companhia do navegador, um embaixador que solicitaria sacerdotes "pera o doctrinarem na fé". A resposta foi afirmativa e o navegador voltaria ao reino de Benim, juntamente com um grupo de missionários, mas também com o objectivo de criar naquela terra uma feitoria. João Afonso tudo fez para que isso fosse possível, ali se estabelecendo para o serviço da Coroa. Se a evangelização da terra não resultou ${ }^{31}$, tendo mesmo os sacerdotes dela desistido, o mesmo se não pode dizer do comércio. Apesar das doenças, provocadas pelo clima, o tráfico foi possível. Ali afluíam escravos que eram depois comprados na Mina pelos mercadores do ouro e "assi em vida de Dom João, como delRey D. Manuel, correo esse resgate de escravos de Benij para a Mina...". João Afonso de Aveiro acabaria por morrer naquela terra, podendo ser considerado o segundo embaixador residente em terras africanas.

E esta mentalidade presidiu à continuação do avanço para sul, avanço que teve o seu ponto alto na expedição comandada por Bartolomeu Dias em 1487. $\mathrm{O}$ navegador recebeu orientações para não fazer "força nem escândalo aos moradores das terras que descobrissem". Quase diríamos que o silêncio era cúmplice na vitória pretendida, por a diplomacia e a estratégia o acompanharem. Com efeito, fizeram-se as escalas já previstas, recolheram-se negros e

homens, porque os desejava ver, e que dahi a quinze luas elle os tornaria, e que pera mais segurança elle leixava entre elles os homens, que tinha enviado ao seu rey." (Barros, op. cit., p. 174)

${ }^{29}$ Barros, op. cit., p 176.

${ }^{30}$ Rui de Pina, Chronica d'ElRey D. João II, com introdução e notas de M. Lopes de Almeida, Porto, 1977, p. 997

31 “....EIRey de Benij era mui subjecto a suas idolatrias, e mais pedia aos sacerdotes por se fazer poderoso contra seus vizinhos com favor nosso, que com desejo de Baptismo, aproveitaram mui pouco os Ministros delle..." (João de Barros, op. cit., p. 179 
deixaram-se outros que regressavam já do reino de Portugal. Com a chegada ao extremo sul do continente africano, havia terminado a curiosidade incerta do começo, agora substituída pela promessa certa do futuro. Bartolomeu Dias foi o último embaixador-descobridor enviado, no século XV, a tão longínquas terras.

As expedições continuaram, numa silenciosa manutenção da anterior actividade. Exemplo dela foi o regresso, certamente em 1489, de Bemoin à sua terra, depois de ter permanecido na corte de D. João II desde 1488. Estando o monarca em Setúbal, recebera-o com todo o cerimonial, ouvindo dele um pedido de socorro para recuperar o trono perdido. No ano seguinte, porque já baptizado, receberia a ajuda pretendida, sendo enviadas, para seu auxílio, "vinte caravelas" ${ }^{32}$, comandadas por Pero Vaz da Cunha, também conhecido por Bizagudo. Além dessa missão, levava também "por regimento de fazer hua fortaleza na entrada do rio de Cenaga" ${ }^{33}$, de modo a completar o escoamento do ouro, fazendo par com S. Jorge da Mina. A expedição não foi bem sucedida, tendo o capitão da armada, por razões ainda hoje incógnitas, assassinado o próprio Bemoin. Pêro Vaz da Cunha era um homem de guerra e não um embaixador!

Entretanto, manteve-se a persistência de D. João II que continuou a enviar os seus homens: Pero d'Évora e Gonçalo Eanes foram como embaixadores ao rei de Tombuctu. Também Rodrigo Rebelo, escudeiro, Pedro Reinel, moço de esporas e João Colaço, besteiro da câmara, seguiram como embaixadores "àquelas partes" da África Central. Com a missão de estabelecer uma feitoria bem no interior, o rei enviaria mais três homens: Rodrigo Reinel, por feitor, Diogo Borges, por escrivão e Gonçalo d'Antes, por homem da feitoria. Estes enviados não precisavam já de ser descobridores, mas apenas emissários e embaixadores.

No período que decorreu até à morte do monarca jamais as terras deixaram de ser visitadas e o comércio revitalizado. Ao criado em busca de glória seguira-se o cavaleiro em nome do Rei. Do assalto e do susto passou-se à negociação. Da permanência eventual surgiu o estabelecimento. Os primeiros descobridores-conquistadores haviam sido substituídos por diplomatas. Aplicara-se já o modelo europeu!

Essa dupla presença é característica do $13^{\circ}$. Rei de Portugal, que rasga um novo horizonte, abrindo África ao conhecimento do velho continente. Por isso, dele pôde dizer D. Fernando de Almeida, na oração de obediência que, em seu nome, apresentou ao papa Alexandre VI “... ele é - digo - aquele Rei que,

\footnotetext{
${ }^{32}$ Garcia de Resende, op. cit., p. 116

${ }^{33}$ Idem, ibidem, p. 116
} 
conhecido pela fama até aos céus, ampliou, como bem se sabe, o género humano com o achamento de outros homens, dilatou o mundo dando ao mundo novas e inúmeras ilhas remotas, e por sua iniciativa tornou certas e conhecidas as que ignorávamos, aumentando assim a Republica Cristã..."34

6. Em jeito de conclusão, poderemos afirmar que, no ocaso do século XV, Portugal não apenas se abrira ao ocidente, mas ao mundo. Com a cristandade vivera em processos paralelos. Com ela acertara projectos políticos. Com ela desenvolvera quadros mentais e culturais, cujos modelos transferiu para as novas paragens.

O ocidente não foi, pois, na época em análise e em termos geográficos, "a casa comum". Mas nesse espaço os povos se reconheciam na mesma identidade religiosa. Só nessa medida podemos afirmar ter existido um sentimento de pertença no espaço europeu - ideia que, um século mais tarde, Luís de Camões traduziria ao colocar na boca de Vasco da Gama as seguintes palavras: "Não somos roubadores, que, passando/ Pelas fracas cidades descuidadas/ A ferro e a fogo as gentes vão matando/ Por roubar-lhe as fazendas cobiçadas;/ Mas, da soberba Europa navegando,/ Imos buscando as terras apartadas/ Da Índia, grande e rica, por mandado/ De um Rei que temos, alto e sublimado." ${ }^{35}$.

${ }^{34}$ Oração de Obediência ao Sumo Pontífice Alexandre VI, dita por D. Fernando de Almeida em 1493, edição com nota bibliográfica de Martim de Albuquerque e tradução portuguesa de Miguel Pinto de Menes, Lisboa, 1988, p. 17.

${ }^{35}$ Luís de Camões, Os Lusiadas, canto II. 